\title{
La enfermedad de Kimura: comunicación de un caso en un varón caucásico y revisión de la literatura
}

\section{Kimura disease: Report of a case in a Caucasian male and revision of the literature}

\author{
J.M. López-Arcas Calleja', T. Martínez Iturriaga², M. Patrón Romero³, G. de María Martínez, \\ J. González Martín-Moro ${ }^{4}$, J.L. del Castillo4
}

Resumen: La enfermedad de Kimura es un trastorno inflamatorio que afecta principalmente a sujetos de origen asiático. Se manifiesta por la existencia de masas de tejido subcutáneo y subplatismal generalmente en la cabeza y el cuello. Suele acompañarse de linadenopatías, y aumento de los niveles de eosinófilos e lgE en sangre periférica. Comunicamos un caso de enfermedad de Kimura, descubierto en un varón caucasiano, tras una biopsia excisional de una masa cervical.

Palabras clave: Enfermedad de Kimura; Hiperplasia angiofolicular; Eosinofili.

Recibido: 07.02.05

Aceptado: 06.10 .06

\begin{abstract}
Kimura disease is a chronic inflammatory disorder mainly involving Asians. It often presents as soft-tissue nodes or lymphadenopathy of the head and neck. Commonly associated with increased levels of eosinophils and IgE in peripheral blood. We report a case of Kimura disease in a Caucasian, diagnosed after lymph node and submaxillary gland removal.
\end{abstract}

Key words: Kimura disease; ALHE; Eosinophil.

1 Médico Residente. Servicio de Cirugía Oral y Maxilofacial. Hospital Universitario La Paz. Madrid, España.

2 Médico Residente. Servicio de Cirugía Oral y Maxilofacial. Hospital Universitario Ramón y Cajal. Madrid, España.

3 Jefe de Sección Anatomía Patológica. Hospital Universitario La Paz. Madrid, España.

4 Médico Residente. Servicio de Cirugía Oral y Maxilofacial. Hospital Universitario La Paz. Madrid, España. 


\section{Introducción}

La enfermedad de Kimura es un trastorno inflamatorio de etiología desconocida que afecta principalmente a sujetos de origen asiático. Clínicamente suele manifestarse por la existencia de masas de tejido subcutáneo y subplatismal, localizadas generalmente en la zona de la cabeza y el cuello, con participación de glándulas salivales y adenopatías regionales. A nivel histopatológico, se caracteriza por la afectación de los nódulos linfáticos en forma de pseudotumores fibroinflamatorios, con hiperplasia de folículos germinales, fibrosis intersticial, marcada infiltración eosinófila de la masa y de los tejidos adyacentes $y$, frecuentemente, eosinofilia con aumento de IgE en sangre periférica.

Comunicamos un caso de enfermedad de Kimura, descubierto en un varón caucasiano, tras una biopsia excisional de una masa cervical.

\section{Caso clínico}

Se presenta en consulta, un varón de raza caucásica y nacionalidad española de 35 años de edad, por presentar una masa cervical, de crecimiento sostenido de tres semanas de evolución. A la inspección y palpación, se objetiva la existencia de una gran masa de consistencia dura, en la región submandibular izquierda de aproximadamente $3 \times 3 \mathrm{~cm}$ así como adenopatías en aparente relación con dicha masa. Se realizó una PAAF con resultado no concluyente, excluyendo origen salivar de la tumoración. Ante la sospecha de tumor de estirpe linfoide debido al rapidísimo creciente de la tumoración, duplicación del volumen tumoral en semanas, se decide realizar biopsia excisional de la masa.

En la cirugía, llevada a cabo con anestesia general, tras un abordaje convencional submandibular, constatamos, la existencia de un gran conglomerado de límites imprecisos, que incluía la masa, 5 o 6 adenopatías de $1 \times 1 \mathrm{~cm}$ adheridas a la misma, y una glándula submandibular de gran tamaño. Se extirparon la masa y las adenopatías en bloque, junto con la glándula, ante la sospecha de que ésta también estuviese afectada.

El diágnostico histopatológico fue enfermedad de Kimura. Posteriormente se completó el estudio, mediante determinación de niveles de eosinófilos e IgE en sangre periférica, así como un sistemático de orina, con proteínas totales en orina, para valorar la función renal del paciente.

En dichos análisis, se apreció una importante elevación de los niveles séricos, de IgE y eosinófilos, sin que se demostrase alteración alguna de la función renal.

\section{Estudio anatomopatológico}

\section{Descripción Macroscópica}

Ganglio linfático que mide 3,5 por $2 \mathrm{~cm}$ y una glándula submaxilar de 4 por $3 \mathrm{~cm}$. A la sección el ganglio linfático tiene un aspecto nodular, observándose una marcada fibrosis capsular. La glándula submaxilar no presenta alteraciones macroscópicas (Fig. 1).

\section{Introduction}

Kimura disease is an inflammatory disorder of unknown etiology that mainly affects individuals of Asian origin. Clinically it tends to manifests as subplatysmal and subcutaneous tissue masses that are located generally in the area of the head and neck. There tends to be salivary gland and regional lymph node involvement. Histopathologically it is characterized by lymphadenopathy in the form of fibroinflammatory pseudotumors, with hyperplasia of germinal follicles, interstitial fibrosis, marked eosinophilic infiltrate of the mass and of adjacent tissue and often there will be eosinophilia and increased levels of serum IgE in peripheral blood.

We report a case of Kimura disease, discovered in a Caucasian male after an excisional biopsy of a neck mass.

\section{Case report}

A 35 year old Spanish Caucasian male presented with a neck mass that had been growing steadily for three weeks. On examination and palpation the existence of a large mass with a hard consistency was noted in the left submandibular region. It measured approximately $3.3 \mathrm{~cm}$ and there was in addition lymphadenopathy that was apparently related to the mass. FNA was carried out and the result was inconclusive, but a tumor of salivary origin was excluded. As a tumor with lymphoid lineage was suspected due to the rapid growth of the tumor, which had doubled in volume in weeks, an excisional biopsy of the mass was carried out.

The surgery was carried out with general anesthesia. After a conventional submandibular approach the existence of a large conglomeration with imprecise edges was confirmed. It contained the mass together with five to six lymph nodes measuring $1.1 \mathrm{~cm}$ that were adhered to it, and a large submandibular gland. The mass and the lymph nodes were excised en bloc together with the gland as it was suspected that it was also affected.

The histopathologic diagnosis was of Kimura disease. The study was later completed by means of the determination of an eosinophilic count and IgE in peripheral blood, as well as a urine test with total protein in urine, in order to evaluate the renal function of the patient.

The analysis showed considerable elevation of serum levels, of IgE and eosinophils but there was no renal function disturbance.

\section{Anatomopathologic study}

Macroscopic description

The lymph node measured 3.5 by $2 \mathrm{~cm}$ and the submaxillary gland 4 by $3 \mathrm{~cm}$. The lymph gland section had a nodular aspect and marked capsular fibrosis could be 


\section{Descripción microscópica}

El ganglio linfático muestra una arquitectura conservada con una intensa hiperplasia folicular reactiva observándose en algunos folículos fenómenos de foliculosis. La cápsula presenta una marcada fibrosis que se extiende hacia el parénquima ganglionar adyacente (Fig. 2). Tanto en el tejido linfoide como en la cápsula se observa una marcada infiltración por eosinófilos. Éstos, a veces forman microabscesos en el interior del tejido linfoide (Fig. 3), mientras que en la cápsula adoptan una disposición preferentemente perivascular, sin que se observen imágenes de vasculitis (Fig. 4). No se ha observado infiltración tumoral a ningún nivel y con técnicas de inmunohistoquímica se demuestran depósitos de lgE a nivel centrofolicular. Con técnicas específicas no se ha demostrado la presencia de parásitos (Fig. 5). Los cortes de la glándula salival remitida muestran sólo pequeños infiltrados linfocitarios con algún eosinófilo en situación periductal. Estos conductos a veces aparecen ligeramente dilatados.

\section{Discusión}

La enfermedad de Kimura fue descrita por primera vez en la literatura china en 1937,1 pero su descripción histopatológica definitiva no llegaría hasta 1948 (Kimura et al.). ${ }^{2}$ Es endémica en Asia (especialmente en China y Japón), pero su frecuencia es extremadamente baja, con unos 200 casos identificados en Asia desde su descripción histológica y de forma esporádica en el resto del mundo. Predominantemente se da en varones con un pico de aparición en la tercera década. En cuanto a la localización, diversas series ${ }^{3}$ confirman que la más frecuente es a nivel de cabeza y cuello (76\%), también región orbitaria, párpados, paladar y faringe, y periféricamente en brazo y axila. 3,6

Clínicamente, la enfermedad de Kimura, suele ser un proceso localizado, simulando en ocasiones una neoplasia, como en nuestro caso. También se han descrito casos con clínica sistémica, 6,7 en forma

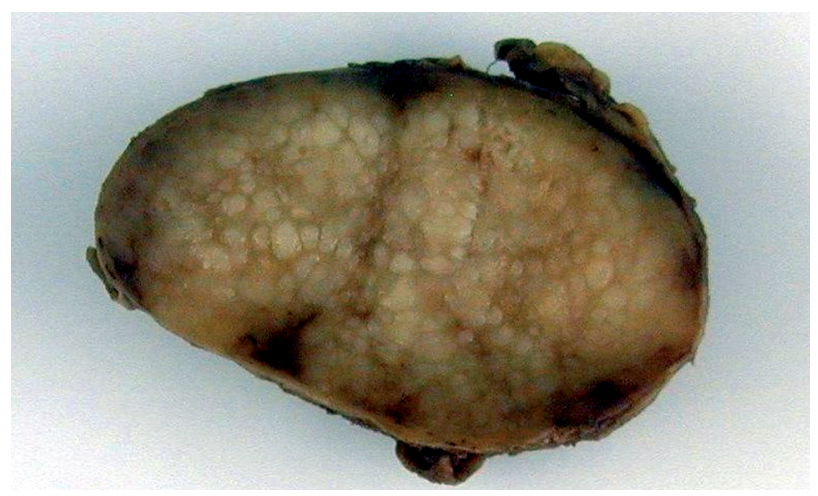

Figura 1. Aspecto macroscópico del ganglio linfático, que al corte presenta una superficie multinodular con marcada fibrosis capsular. Figure 1. Macroscopic appearance of lymph node. The section shows a multinodular surface with marked capsular fibrosis.

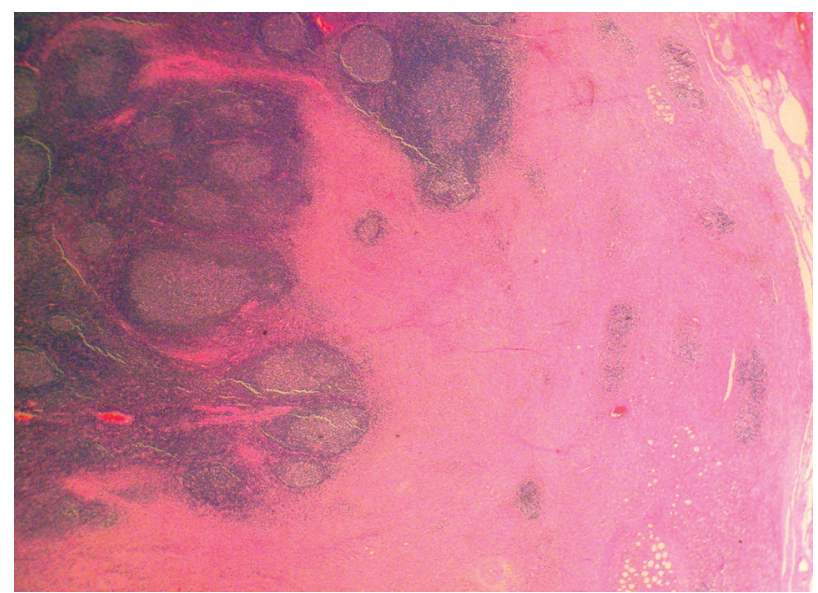

Figura 2. Ganglio linfático con intensa hiperplasia de los folículos linfoides e intensa fibrosis capsular que se extiende hacia el interior del tejido linfoide.

Figure 2. Lymph node with intense hyperplasia of lymph follicles and intense capsular fibrosis extending towards the inside of the lymphoid tissue.

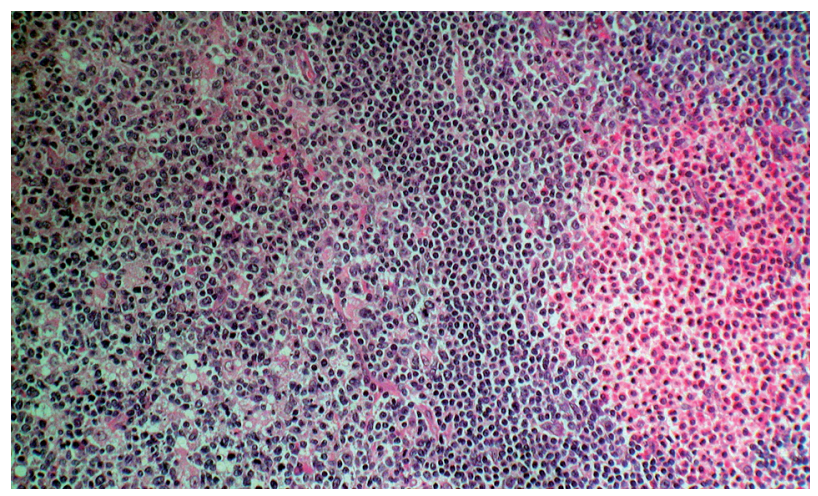

Figura 3. Infiltración eosinofílica con formación de microabcesos en la vecindad de un folículo que muestra imágenes de foliculolisis.

Figure 3. Eosinophilic infiltration with microabscess formation in the area of a follicle showing signs of folliculosis. observed. The submaxillary gland did not display any macroscopic disturbance (Fig. 1).

\section{Microscopic description}

The lymph gland had conservative architecture with intense reactive follicular hyperplasia and some follicles indicative of folliculosis could be observed. The capsule showed marked fibrosis that extended towards the adjacent lymph node parenchyma (Fig. 2). The lymph tissue as well as the capsule showed marked eosinophilic infiltration. These in turn formed microabscesses in the interior of the lymphoid tissue (Fig. 3), while in the capsule they had a mainly perivascular distribution. Vasculitis was not observed (Fig. 4). Nor was tumor infiltration observed at any point. IgE deposits were shown in the follicle centers through immunohistochemical techniques. Specific techniques were not able to reveal the presence of parasites (Fig.5). The salivary gland sections sent away showed only small lymphocytic infiltrates with some periductal infiltration of eosinophils. These ducts sometimes appeared slightly dilated.

\section{Discussion}

Kimura disease was first described in the Chinese literature in 1937,1 but its definitive histopathologic description was not until 1948 (Kimura el al.). ${ }^{2}$ It is endemic in Asia (especially in China and Japan), but it is extremely uncommon with 200 cases identified in Asia since its histological description, and it has been identified 
de prurito, eczema, urticaria, etc., pero son los menos y más frecuentemente es su asociación con patología renal (aprox. 50\% de casos), generalmente en forma de glomerulonefritis extramembranosa, pudiéndose desarrollar ésta en fases previas al crecimiento de la masa cervical, que no aparecían en nuestro paciente.

Uno de los principales problemas que presenta la enfermedad de Kimura es la dificultad que supone su diagnóstico. No sólo es una entidad extremadamente rara en la población general, sino que necesita un diagnóstico clínico-patológico preciso, para poder distinguirla de otras entidades con características similares como el Linfoma de Hodgkin, enfermedad de Castleman, linfadenopatía dermatopática, granulomatosis alérgica de Churg Strauss, linfadenitis parasitarias y ALHE. En nuestro caso, solamente el estudio anatomopatológico de la pieza permitió el diagnóstico, siendo la citología absolutamente inespecífica.

Precisamente, con ésta última entidad se han producido numerosas confusiones en la literatura. Inicialmente se consideró que tanto la ALHE, como la enfermedad de Kimura, clínicamente similares, suponían dos variedades de una misma entidad clinicopatológica. No sería hasta 1979 que ambas entidades fueron claramente diferenciadas,

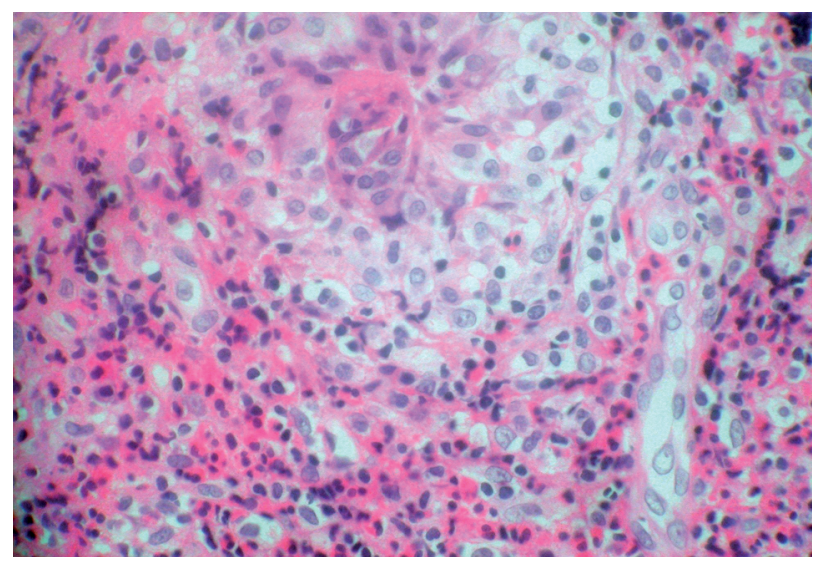

Figura 4. Ocasionalmente en situación capsular se observan granulomas constituidos por histiocitos de morfología epitelioide. Figure 4. Granulomas made up of histiocytes with an epithelioid morphology can be seen incidentally in the capsule.

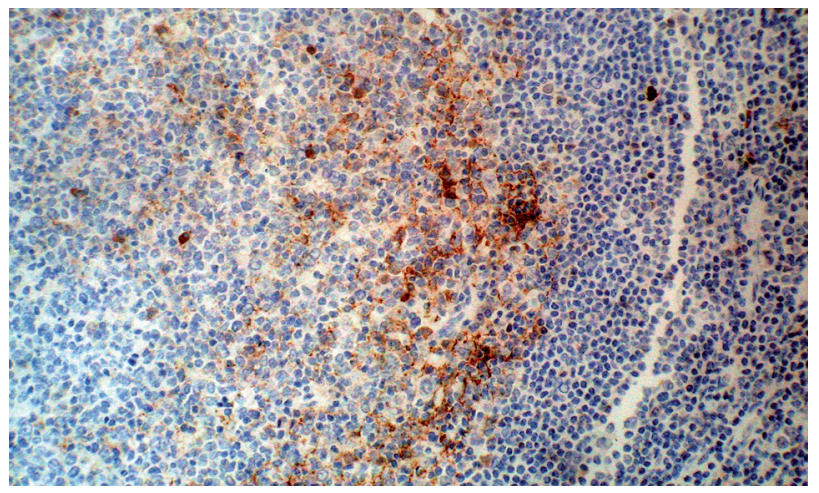

Figura 5. Con técnicas de IMH se observan depósitos de IgE a nivel del centro germinal.

Figure 5. IgE deposits can be observed by the germinal center with IMH techniques. sporadically in the rest of the world. There is a male predominance and the peak incidence is in the third decade. With regard to location, various series ${ }^{3}$ have confirmed that the most common location is the head and the neck (76\%), also the orbital region, eyelids, palate and pharynx, and peripherally the arms and armpits.3,6 Clinically Kimura disease tends to be a localized process, simulating on occasions a neoplasm, as occurred in our case. Cases with systemic clinical signs have been described 6,7 in the form of pruritus, eczema, rashes etc., but this is less common and its association with renal pathology is more common (approximately $50 \%$ of cases), generally in the form of extramembranous glomerulonephritis that can develop before the growth phase of the neck mass, but this did not occur in our patient.

One of the principal problems with Kimura disease is the difficulty diagnosing it. Not only is it an extremely rare entity in the general englobando a ALHE dentro del grupo de los hemangiomas histiocitoides. Las diferencias entre ambas entidades están expuestas someramente en el siguiente cuadro (Tabla 1).

La etiología del Kimura, constituye todavía una incógnita. Se postula que pueda ser una enfermedad autoinmune. ${ }^{9}$ La evidencia de eosinofilia periférica, incremento de mastocitos y niveles aumentados de IL-5 e IgE, hacen pensar en una estimulación anormal de los linfocitos $\mathrm{T}$, de forma similar a lo q sucede en las reacciones de hipersensibilidad. La importante hiperplasia folicular, podría sugerir un posible estado de inmunodeficiencia e infección por $\mathrm{VHH}-8$, si embargo esto no ha podido ser demostrado. ${ }^{10}$

En cuanto al tratamiento de la enfermedad de Kimura, señalar simplemente que la cirugía constituye el principal tratamiento, siendo otras alternativas, la corticoterapia, radio e incluso quimioterapia. A pesar del escaso periodo de seguimiento postoperatorio (10 meses) el paciente se encuentra actualmente libre de enfermedad. Con cualquiera de ellos la recurrencia de la enfermedad tras el tratamiento, es bastante frecuente. population, but it requires a precise clinico-pathologic diagnosis in order to distinguish it from other entities with similar characteristics such and Hodgkin's lymphoma, Castleman's disease, dermatopathic lymphadenopathy, ChurgStrauss allergic granulomatosis, parasitic lymphadenitis and ALHE. In our case, only the anatomopathologic study of the sample permitted the diagnosis as the cytology was totally unspecific.

In fact there has been much confusion in the literature with the latter. Initially it was considered that ALHE as well as Kimura disease were clinically similar, and that they represented two varieties of the same clinicopathologic entity. It was not until 1979 that both entities were clearly differentiated, with ALHE being encompassed in the histiocytoid hemangioma group. The differences between both entities are superficially exposed in the following table.

The etiology behind Kimura is still unknown. It has been postulated that it could be an autoimmune disease. ${ }^{9}$ The evidence of peripheral eosinophilia, the increase in mastocytes 
Tabla 1. Cuadro comparativo

\section{Enfermedad de Kimura}

- Hombres jóvenes ( $2^{\mathrm{a}}-3^{\mathrm{a}}$ década)

- Orientales

- Masas subcutáneas voluminosas con adenopatías y afectación glánd. salivales

- Hiperplasia folicular, infiltración eosinófila de la zona perivascular e interfolicular con formación de abscesos y proliferación vénulas postcapilares

- Elevación IgE total, Hipereosinofilia

- Patología benigna

\section{Hiperplasia angiofolicular con eosinofilia}

- Mujeres de mediana edad ( $3^{\mathrm{a}}-5^{\mathrm{a}}$ década)

- Occidentales

- Papulonódulos dérmicos o subcutáneos en región cervical. iel supradyacente eritematosa y igmentada.

- Aspecto similar. Vasos histiocitoides con células endoteliales peculiares (núcleos de diferente tamaño y protrusión en la luz del vaso)

- IgE no elevada, Hipereosinofilia

- Forma benigna de un grupo de enfermedades caracterizadas por proliferaciones vasculares que abarca desde el hemangioendotelioma al angiosarcoma epiteliode.

Table 1. Comparative table

\section{Kimura disease}

- Young males (2nd-3rd decade)

- Orientals

- Subcutaneous voluminous masses with lymph node and salivary gland involvement

- Follicular hyperplasia, eosinophilic infiltration in the perivascular and interfollicular area with abscess formation and postcapillary venules

- Increase in total IgE, Hypereosinophilia

- Benign pathology

\section{Angiofollicular hyperplasia with eosinophilia}

- Middle aged females (3rd-5th decades)

- Occidentals

- Dermal or subcutaneous papular nodules in the neck region.

- Erythematous and pigmented overlying skin.

- Similar appearance. Histiocytoid vessels with characteristic endothelial cells (different sized nuclei and lumen protrusion)

- $\lg$ E is not elevated, Hypereosinophilia

- Benign form of a group of diseases characterized by vascular proliferation from hemangioendothelioma to epithelioid angiosarcoma.

\section{Conclusiones}

La enfermedad de Kimura es una enfermedad inflamatoria caracterizada por una intensa infiltración eosinófila de ganglios linfáticos y a veces tejido celular subcutáneo. Epidemiológicamente afecta fundamentalmente a varones de raza asiática. La localización en cabeza y cuello es la más frecuente, y debe ser tenido en cuenta por cualquier cirujano maxilofacial.

\section{Bibliografía}

1. Kim HT, Szeto C. Eosinophilic hyperplastic lymphogranuloma: comparison with Mickulicz's disease. Chin Med / 1937;23:699.

2. Kimura T, Yoshimura S, Ishikama E. On the unusual granulation combined with hyperplastic changes of lymphatic tissues. Trans Soc Pathol Jpn 1948;37:178-80.

3. Chan JK, Hui Pk, Hg CS, y cols. Epithelioid haemangioma (angiolymphoid hyperplasia with eosinophilia) and Kimura's disease in Chinese. Histopathology 1989;15:557-74.

4. Irish JC, Kain K, Keystone JS, Gullane PJ. Kimura's disease: an unusual cause of head and neck masses. J Otolaryngol 1994;23:88-91.

5. Som PM, Biller HF. Kimura disease involving parotid gland and cervical nodes: CT and MR findings. / Comput Assist Tomogr 1992;16:320-2. and increased levels of IL-5 suggest abnormal stimulation of $T$ lymphocytes similar to hypersensitivity reactions. The considerable follicular hyperplasia could be suggestive of a possible state of immunodeficiency and $\mathrm{VH}-8$ infection, however, it has not been possible to demonstrate this. ${ }^{10}$

With regard to treatment for Kimura disease, it should be pointed out that surgery constitutes the main treatment with corticotherapy, radiotherapy and even chemotherapy being alternatives. In spite of the limited postoperative follow-up period (10 months) the patient is currently free of disease. Recurrence of the disease after any of these treatments is quite common.

\section{Conclusions}

Kimura disease is an inflammatory disease that is characterized by intense eosinophilic infiltration of the lymph nodes and sometimes of subcutaneous cellular tissue. Epidemiologically it mainly affects males of Asiatic origin. It is most commonly located in the head and neck and the maxillofacial surgeon should keep this in mind. 
6. Li Tj, Chen XM, Wang SZ, et al. Kimura's disease: a clinicopathological study of 54 Chinese patients. Oral Surg Oral Med Oral Pathol Oral Radiol Endod 1996;82:549-55.

7. Atar S, Oberman AS, Ben-Izhak O, Flatou E. Recurrent nephrotic syndrome associated with Kimura's disease in a young non-Oriental male. Nephron 1994;68:259-61.

8. Mitsui M, Ogino S, Ochi K, y cols. Thrree cases of eosinophilic lymphfolliculoid granuloma of the soft tissue originating from the parotid gland. Acta Otolaryngol Suppl 1996;522:130-2.

9. Jang KA, Ahn SJ, Choi JH, y cols. Polymerase chain reaction (PCR) for human herpesvirus 8 and heteroduplex PCR for clonality assessment in angiolymphoid hyperplasia with eosinophlia with kimura disease. J Cutan Pathol 2001;28:363-7.
10. Koo BP, Chan R. Kimura disease: 2 case reports and a literature review. Cutis 2002;70:57-62.

11. Chartapisak W, Opastirakul S.Steroid-resistant nephritic syndrome associated with kimura's disease. Am J Neph 2002;22:381-384.

12. Day TA, Abreo F, Hoajsoe DK, Aarstad RF. Treatment of Kimura's disease: a therapeutic enigma. Otololaryngol Head Neck Surg 1995;112:333-7.

13. Chun SI, Ji HG. Kimura's disease and angiolymphoid hyperplasia with eosinophilia: clinical and histhopathological differences. J Am Acad Deramtol 1992;27:954-8.

14. Itami J, Miyoshi T, Ogata H, Miwia K. Radiation therapy in Kimura's disease. Acta Oncol 1989;28:511-4.

15. Ingrams DR, Stafford ND, Creagh TM. Angiolymphoid hyperplasia with eosinophilia. / Laryngol Oncol 1995;109:262-4. 